\title{
Optimization of anti-proliferative activity using a screening approach with a series of bis-heterocyclic G-quadruplex ligands
}

\author{
Stephan A. Ohnmacht, Cristina Ciancimino, Giulia Vignaroli, Mekala Gunaratnam, Stephen Neidle* \\ UCL School of Pharmacy, University College London, WC1N 1AX London, UK
}

\section{A R T I C L E I N F O}

\section{Article history:}

Received 19 June 2013

Revised 18 July 2013

Accepted 24 July 2013

Available online 1 August 2013

\section{Keywords:}

Quadruplex

Anti-proliferative

Phenotypic screening

Telomerase

Oxazoles

\begin{abstract}
A B S T R A C T
Using a phenotypic screening and SAR optimization approach, a phenyl-bis-oxazole derivative has been identified with anti-proliferative activity, optimized with the use of a panel of cancer cell lines. The lead compound was synthesized by means of a short and effective two-step synthesis using Pd-catalyzed direct arylation. The compound stabilizes several quadruplex DNA sequences including a human telomeric DNA and one from the promoter of the HSP90 gene, although the structure-activity relationships of the series are not obviously related to the quadruplex binding.
\end{abstract}

(c) 2013 Elsevier Ltd. All rights reserved.
The targeting of G-tracts in genomic DNA that can fold into higher-order quadruplex structures, ${ }^{1-3}$ with the aid of small molecules, ${ }^{4}$ is emerging as a novel approach to cancer therapy, and may well have applications in other diseases. This concept has recently been validated by the direct visualization of quadruplex DNA in human cells and by the finding that they can be stabilized by small molecules. ${ }^{5}$ Many first- and second-generation quadruplex-binding and stabilizing ligands share common features of large planar surface areas and pendant cationic side-chains. Some have high $\left(>10^{3}\right)$ selectivity for quadruplex over duplex DNA and have shown selectivity for cancer cell types over normal cells. Few have progressed to in vivo evaluation in human cancers, in part because of the perception that their features are insufficiently drug-like. More recently, a number of families of non-polycyclic quadruplex ligands have also been described, some of which have selectivity for particular promoter quadruplexes, ${ }^{3}$ such as those encoded in the c-MYC, ${ }^{6}$ c-KIT ${ }^{7}$ and $\mathrm{HSP}^{8}{ }^{8}$ promoter sequences. A large number of such quadruplex DNA targets are likely to exist, very few of which have yet been validated. This raises the challenge that even if selectivity for a chosen quadruplex is achieved, there is currently no straightforward approach that can be taken to ensure that such a target is unique within quadruplex space, although it is highly likely that particular quadruplexes can have unique sequences and tertiary structures. An example of this is shown by the (two) quadruplexes encoded in the c-KIT promoter. ${ }^{9}$ Telomeric quadruplexes may also have unique features since the length of

\footnotetext{
* Corresponding author.

E-mail address: s.neidle@ucl.ac.uk (S. Neidle).
}

the single-stranded telomeric DNA sequence is sufficient for several consecutive quadruplexes to be formed from it. ${ }^{10}$

Optimization of biological activity for a given library of compounds has for the most part utilized structure-activity data obtained from quadruplex affinity measurements. Structure-based molecular design using crystallographic or NMR information has mostly focused on telomeric ${ }^{11}$ or c-MYC quadruplexes, ${ }^{12}$ simply because of the lack of structural data on many other potential quadruplex targets. We present here an alternative approach that starts with a family of quadruplex binding compounds and optimizes them by means of several cycles of phenotypic screening for anti-proliferative activity in a panel of cancer cell lines. This does not rely on the assumption of any particular quadruplex target, and we cannot discount the possibility that there may be alternative non-quadruplex targets involved.

We have previously identified a series of para-disubstituted phenyl-bis-triazoles (Fig. 1, compound I) as well as a focused library of disubstituted naphthyl-bis-triazoles (of which compound CL67 (II) emerged as the lead quadruplex-binding compound targeting the HIF- $1 \alpha$ pathway, ${ }^{13}$ presumed to be via a HIF- $1 \alpha$ promoter quadruplex ${ }^{14}$ ). Separately we have shown that a series of disubstituted phenyl bis-oxazole compounds has selectivity for the (hitherto unreported) promoter quadruplexes in the HSP90 gene. $^{8}$

This series of HSP90 promoter quadruplex-binding compounds have to date shown significant broad-spectrum anti-proliferative activity in a panel of human carcinoma cell lines, which includes the MCF-7 breast cancer line. In addition, a closely-related small library of meta-disubstituted phenyl-bis-triazoles (III) has yielded 

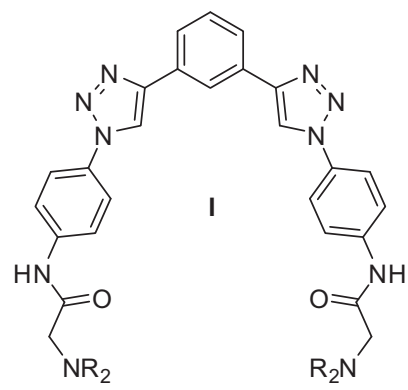<smiles>CCNCC(=O)Nc1cccc(-n2cc(-c3ccc4ccc(-c5cn(-c6cccc(NC(=O)CNCC)c6)nn5)cc4c3)nn2)c1</smiles><smiles>[R16]CNC(=O)CNc1cccc(-n2cc(-c3cccc(-c4cn(-c5cccc(NC(=O)CN[R20])c5)nn4)c3)nn2)c1</smiles>

Figure 1. Three bis-triazole frameworks all of which lack low $\mu \mathrm{M}$ in vitro potency against MCF7 breast cancer cells.

no potent lead compound that fulfills the criteria of activity towards MCF7 cells. As part of ongoing optimization studies of compound CL67 (with an $\mathrm{IC}_{50}$ value of $>25 \mu \mathrm{M}$ in the MCF-7 breast carcinoma cell line) we have recently discovered that small structural modifications influencing, among other factors, lipophilicity, can lead to very large changes in biological profile. We describe here the design, synthesis and biological evaluation of this particular class of compounds and have found that a phenotypic screening approach as a tool for SAR optimization is superior to considerations of in vitro quadruplex binding.

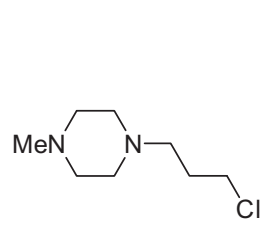<smiles>Nc1ccncc1</smiles>

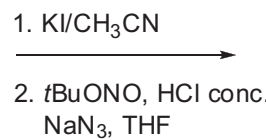<smiles>CN1CCN(CCCNc2cccnc2)CC1</smiles><smiles>Nc1cccc(Br)c1</smiles><smiles>CN1CCN(CCCNc2cccc(Br)c2)CC1</smiles><smiles>CN1CCN(CCCNc2ccc(-n3cc(-c4ccc5ccc(-c6cn(-c7ccc(NCCCN8CCN(C)CC8)cc7)nn6)cc5c4)nn3)cc2)CC1</smiles><smiles>CN1CCN(CCCNc2cccc(-n3cc(-c4ccc5ccc(-c6cn(-c7cccc(NCCCN8CCN(C)CC8)c7)nn6)cc5c4)nn3)c2)CC1</smiles><smiles>C#Cc1ccc2ccc(C#C)cc2c1</smiles><smiles>CN1CCN(CCCNc2cccc(-c3ncc(-c4ccc5ccc(-c6cnc(-c7cccc(NCCCN8CCN(C)CC8)c7)o6)cc5c4)o3)c2)CC1</smiles>
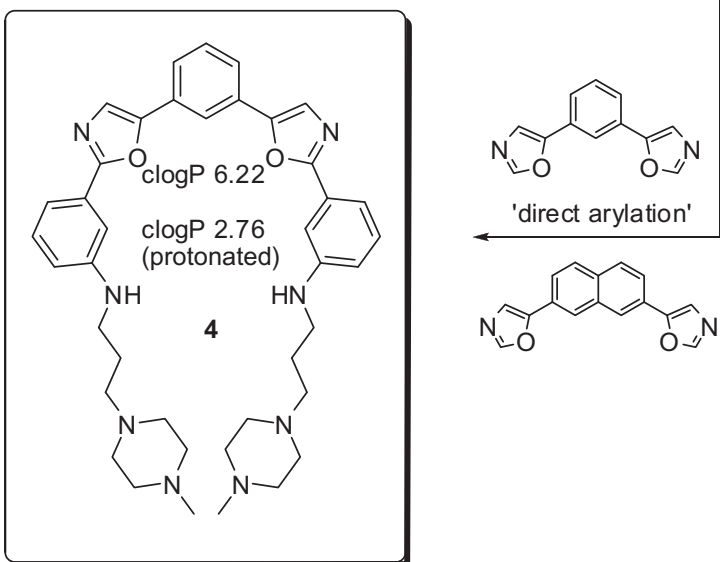

Scheme 1. Synthetic pathway for the preparation of final bis-heterocyclic compounds 1-4. 
Our synthetic efforts initially focused on a $\mathrm{Cu}[\mathrm{I}]$-catalyzed 1,3dipolar cycloaddition, ${ }^{15}$ which allowed us to gain access to compounds $\mathbf{1}$ and $\mathbf{2}$. This approach was subsequently expanded to include a direct arylation reaction giving rapid access to compounds 3 and $\mathbf{4}$. The Scheme highlights the synthetic approach in more detail. Commercially available 1-(3-chloropropyl)-4methyl-piperazine was reacted in two separate reactions with meta-phenylenediamine and 3-bromo-aniline, respectively. The meta-halogenated analogue was isolated, purified over silica and directly employed in a direct arylation reaction using pivalic acid and a palladium catalyst to give final compounds 3 and $4 .^{16}$ The azide precursor utilized in the cycloaddition reaction was generated via the standard sodium azide $/{ }^{t} \mathrm{BuONO}$ protocol. ${ }^{17}$ Finally, a click reaction was used to generate target compounds $\mathbf{1}$ and $\mathbf{2}$. A number of end-groups and side-chain lengths have been explored, but here the focus is on the $N$-methyl-piperazine substituted compounds in view of earlier studies indicating that this is a favored end-group. ${ }^{18}$

A 96 h sulforhodamine B (SRB) assay ${ }^{19}$ to evaluate the anti-proliferative activity of 1 showed that IC $_{50}$ values were above $25 \mu \mathrm{M}$ for all lines in a small panel of cancer cell lines (Table 2). A second round of cellular evaluation examined the effects of modifying the substitution pattern on the terminal phenyl ring system from para to meta. This did not enhance potency, as judged by lower $\mathrm{IC}_{50}$ values in the MCF7 and A549 cell lines (compound 2), but a significant decrease in $\mathrm{IC}_{50}$ value for the two renal cancer cell lines was observed. This is in accord with previous findings for compound CL67, ${ }^{13}$ which has highly selective activity in renal compared to a number of other carcinoma cell lines and suggests that the meta substitution may be a critical factor in this selectivity. As the initial rationale for these compounds was to further develop a SAR study on CL67, it was decided to alter the linking heterocyclic moiety from a triazole to an oxazole ring, which would contribute to an overall increase in lipophilicity and possibly also stability in particular, as the oxazoles are aryl-substituted at the 2-position.

Compound 3 was generated using our previously-reported approach $^{8}$ using a direct arylation/C-H activation step to facilitate the late-stage introduction of the polar side-chains (Scheme 1). The third round of cellular evaluation using compound $\mathbf{3}$ showed a significant improvement in anti-proliferative activity (Table 2), with $\mathrm{IC}_{50}$ values in all the cell lines of between 1.2 and $2.1 \mu \mathrm{M}$, the sole structural difference being two oxazole rings replacing two triazoles. This is a conservative structural change yet results in a sig-

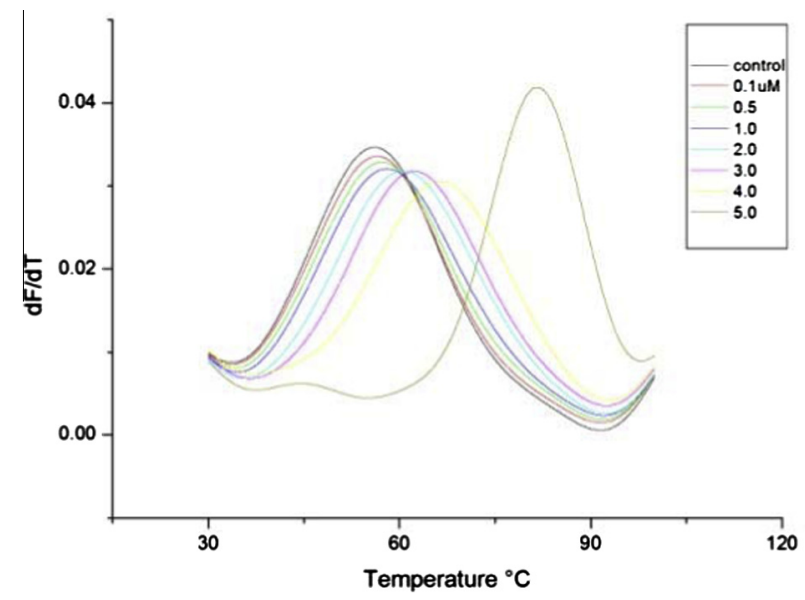

Figure 2. FRET melting curve for compound 4 with the 21-mer Hsp90A promoter quadruplex sequence at different ligand concentrations. There is a significant shift in melting temperature $\left(T_{\mathrm{m}}\right)$ for compound $\mathbf{4}$ at the $5 \mu \mathrm{M}$ concentration, whereas there is little shift at the lower concentrations. nificant change in $c \log P$ values on account of the differences in electronic character between the two rings. The fourth and final round of cellular evaluation involved the phenyl analogue 4 of compound 3, with a $>1$ unit $\operatorname{lower} c \log P$ value. This is slightly and consistently more potent in the cell lines of this panel. Several shorter side-chain length meta-disubstituted phenyl bis-oxazoles (5-8) have also been synthesized and similarly show potency across the cancer cell line panel, including in MCF7 cells (Fig. 3, Ta-
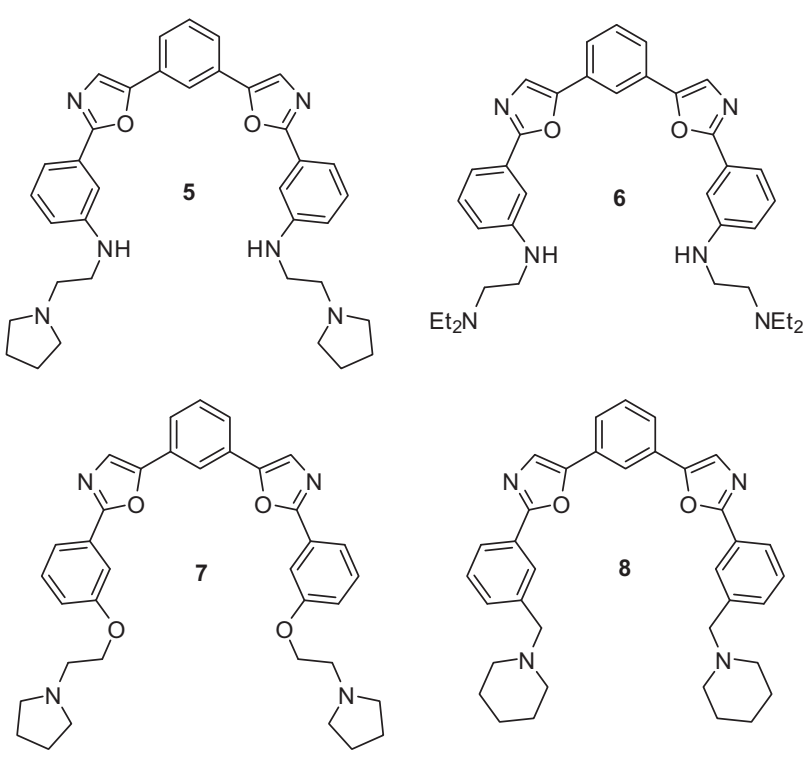

Figure 3. Expanded focused library of meta-disubstituted phenyl-bis-oxazoles (58) with broad spectrum anti-proliferative activities.

Table 1

$\Delta T_{\mathrm{m}}$ Values $\left({ }^{\circ} \mathrm{C}\right)$ for FRET analyses of compounds 1-8 at 1 and $5 \mu \mathrm{M}$ concentrations with a series of quadruplex-forming DNA sequences: F21T, c-KIT2, HSP90A

\begin{tabular}{|c|c|c|c|c|c|c|c|c|}
\hline \multirow[b]{2}{*}{$\mu \mathrm{M}$} & \multicolumn{2}{|c|}{ F21T } & \multicolumn{2}{|c|}{ c-KIT2 } & \multicolumn{2}{|c|}{ HSP90A } & \multicolumn{2}{|c|}{ dsDNA } \\
\hline & 1 & 5 & 1 & 5 & 1 & 5 & 1 & 5 \\
\hline 1 & $<2$ & $<10$ & $<2$ & $<10$ & $<2$ & $<10$ & 0 & 0 \\
\hline 2 & 2.9 & $<10$ & 2.4 & $<10$ & 5.7 & $<10$ & 0 & 0 \\
\hline 3 & $<2$ & $<10$ & $<2$ & $<10$ & 2.5 & $<10$ & 0 & 0 \\
\hline 4 & $<2$ & 20.1 & $<2$ & 18.3 & $<2$ & 25.6 & 0 & 0 \\
\hline 5 & $<2$ & 24.7 & $<2$ & 17.0 & $<2$ & $\mathrm{n} / \mathrm{a}$ & 0 & 6.8 \\
\hline 6 & $<2$ & 13.3 & $<2$ & 13.6 & $<2$ & 19.5 & 0 & 0 \\
\hline 7 & $<2$ & 25.9 & $<2$ & 20.3 & 3.4 & 27.7 & 0 & 5.3 \\
\hline 8 & $<2$ & $\mathrm{n} / \mathrm{a}$ & $<2$ & $\mathrm{n} / \mathrm{a}$ & 5.0 & $\mathrm{n} / \mathrm{a}$ & 2.0 & $\mathrm{n} / \mathrm{a}$ \\
\hline
\end{tabular}

dsDNA represents duplex DNA.

Esds are from triplicate measurements and average $0.3^{\circ} \mathrm{C}$.

Table 2

Short-term anti-proliferative activity ( $\mathrm{IC}_{50}$ values in $\mu \mathrm{M}$ ) for compounds $\mathbf{1 - 8}$, in a cancer cell line panel, comprising MCF7 (breast), 786-O/RCC4 (renal), A549 (lung cancer) and WI38 (fibroblast) cell lines, determined using a $96 \mathrm{~h}$ SRB assay

\begin{tabular}{llllll}
\hline \multicolumn{5}{c}{ Short term IC 50} \\
\hline $\mathbf{1}$ & MCF-7 & $786-0$ & RCC4 & A549 & WI38 \\
\hline $\mathbf{2}$ & $>25$ & $>25$ & $>25$ & $>25$ & $>25$ \\
$\mathbf{3}$ & $1.9 \pm 0.2$ & $1.2 \pm 0.3$ & $2.1 \pm 0.1$ & $1.6 \pm 0.3$ & $3.1 \pm 0.2$ \\
$\mathbf{4}$ & $1.0 \pm 0.2$ & $0.9 \pm 0.1$ & $1.2 \pm 0.2$ & $1.2 \pm 0.4$ & $1.1 \pm 0.2$ \\
$\mathbf{5}$ & $2.1 \pm 0.5$ & $1.1 \pm 0.3$ & $1.1 \pm 0.1$ & $0.6 \pm 0.1$ & $1.0 \pm 0.1$ \\
$\mathbf{6}$ & $3.1 \pm 0.2$ & $1.3 \pm 0.1$ & $1.1 \pm 0.1$ & $2.5 \pm 0.4$ & $2.8 \pm 0.2$ \\
$\mathbf{7}$ & $1.2 \pm 0.3$ & $0.7 \pm 0.1$ & $1.3 \pm 0.1$ & $1.0 \pm 0.2$ & $1.0 \pm 0.3$ \\
$\mathbf{8}$ & $1.4 \pm 0.2$ & $2.3 \pm 0.2$ & $1.9 \pm 0.3$ & $1.2 \pm 0.1$ & $4.4 \pm 0.2$ \\
\hline
\end{tabular}

Esds are from triplicate (or more) measurements. IC $_{50}$ values shown as $>25 \mu \mathrm{M}$ are all substantially above this value and were not determined with equivalent accuracy. 

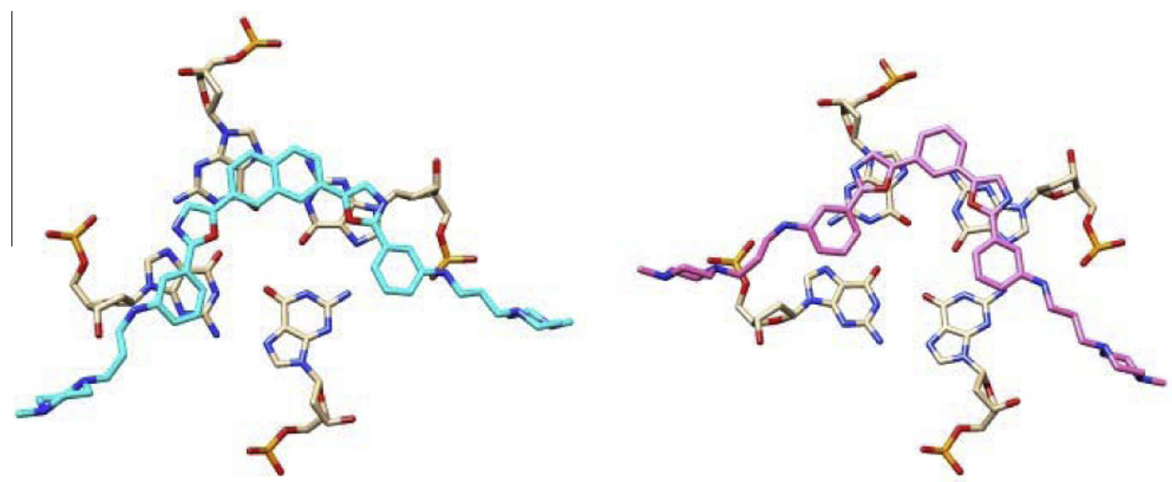

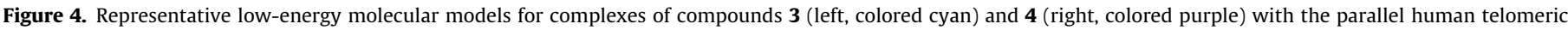

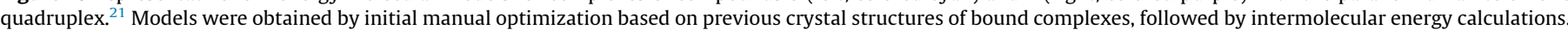

ble 2). This strongly suggests that side chain length is not critical for enhanced cellular activity.

An initial rationale for the development of these and other related ligands has been that they act by interacting with cellular G-quadruplexes such as those in human telomeres or in various promoter sequences of oncogenic genes. We have previously shown that the para-substituted phenyl-bis-oxazole framework has selectivity for a quadruplex encoded in the promoter of the HSP90 gene. Data from a FRET assay ${ }^{20}$ (Table 1) shows that compounds 1-3 do not stabilize a human telomeric quadruplex sequence (F21T). However compound $\mathbf{4}$ (as well as $\mathbf{5}$ and $\mathbf{7}$, although some duplex DNA binding is evident for these two compounds) does have a significant stabilizing effect on this quadruplex as well as on the HSP90 and c-KIT2 quadruplexes, albeit at higher concentrations (Table 1). Compound $\mathbf{4}$ does not stabilize double-stranded DNA in the range of concentrations used.

An initial molecular modeling examination of the potential interactions between compounds $\mathbf{3}$ and $\mathbf{4}$ and the parallel human telomeric quadruplex crystal structure ${ }^{21}$ has been undertaken (Fig. 4). The parallel topology was chosen since it has been observed in all ligand-telomeric quadruplex crystal structures determined to date. ${ }^{11}$ The study suggests that there are unlikely to be major differences between the two complexes, although the smaller size of the core groups in compound $\mathbf{4}$ may result in improved stacking of the two oxazole groups with adjacent guanine rings. This is in accord with the slightly superior stabilization observed in the FRET assays with compounds 4-8 at high ligand concentrations (Fig. 2). We cannot rule out, and at this stage, have not examined, alternative binding modes involving groove interactions, although it is possible that they might explain the large differences in biological responses between compounds 1,2 and 3, 4. No relevant experimental data on these alternative binding modes is currently available.

In summary this study has shown that in this series of compounds the determinants of optimal anti-proliferative potency are:

1. The possession of a central phenyl ring.

2. Two attached phenyl-oxazole rings.

3. These should bemeta attached to the phenyl rings.

4. The length of the linker and nature of the terminal group is of lesser importance.

It is premature to propose that the cellular mode of action of these compounds involves G-quadruplex stabilization since by comparison previously-reported phenyl-bis-oxazoles and triazoles have shown superior stabilization ability with several quadruplex sequences (HSP90A and the human telomeric quadruplexes) yet with comparable anti-proliferative abilities. Few of the bis-triazole and oxazole derivatives presented here had any significant quadruplex stabilization in FRET assays. Only at high concentrations (5 $\mu \mathrm{M}$ of compounds 4-7) was there significant stabilization in the FRET assay (accurate curve fitting for compound $\mathbf{8}$ was not possible at $5 \mu \mathrm{M}$, so no FRET data is available at this concentration). This suggests that either the compounds act at other quadruplex loci that are yet to be determined, or that the compounds act by non-quadruplex mechanisms. Regardless of quadruplex target, we suggest that cell-based phenotypic screening can speedily optimize anti-proliferative activity in these series. This may be an useful approach to obtaining poly-targeted quadruplex-binding compounds with high biological activity and good pharmacological profiles. The compounds presented here have some structural resemblance to kinase inhibitors, although there is no indication that they interact with kinases-the related compound CL67 shows no activity in a large kinase panel (Welsh et al., unpublished observations).

\section{Acknowledgments}

S.A.O. and C.C. contributed equally to this work. We are grateful to Cancer Research UK (Programme Grant No. C129/A4489 to S.N.). The Novartis Institute of BioMedical Research, Boston, is thanked for obtaining CL67 data in their kinase panel.

\section{References and notes}

1. (a) Patel, D. J.; Phan, A. T.; Kuryavyi, V. Nucleic Acids Res. 2007, 35, 7429; (b) Burge, S.; Parkinson, G. N.; Hazel, P.; Todd, A. K.; Neidle, S. Nucleic Acids Res. 2006, 34, 5402; (c) Neidle, S. Curr. Opin. Struct. Biol. 2009, 19, 1; (d) Oganesian, L.; Bryan, T. M. BioEssays 2007, 25, 155.

2. (a) Huppert, J. L.; Balasubramanian, S. Nucleic Acids Res. 2005, 33, 2908; (b) Todd, A. K.; Johnston, M.; Neidle, S. Nucleic Acids Res. 2005, 33, 2901.

3. (a) Huppert, J. L.; Balasubramanian, S. Nucleic Acids Res. 2007, 35, 406; (b) Siddiqui-Jain, A.; Grand, C. L. Bearss, D. J. Hurley, L. H. Proc. Natl. Acad Sci. U.S.A. 2002, 99, 11593; (c) Balasubramanian, S.; Hurley, L. H.; Neidle, S. Nat. Rev. Drug Disc. 2011, 10, 261.

4. See for example: (a) Sun, D.; Thompson, B.; Cathers, B. E.; Salazar, M.; Kerwin, S M.; Trent, J. O.; Jenkins, T. C.; Neidle, S.; Hurley, L. H. J. Med. Chem. 1997, 40, 2113; (b) Monchaud, D.; Teulade-Fichou, M.-P. Org. Biomol. Chem. 2008, 6, 627; (c) Ou, T.-M.; Lu, Y.-J.; Tan, J.-H.; Huang, Z.-S.; Wong, K.-Y.; Gu, L.-Q ChemMedChem 2008, 3, 690; (d) Franceschin, M. Eur. J. Org. Chem. 2009, 2225; (e) Yang, D. Z.; Okamoto, K. Future Med. Chem. 2010, 2, 619; (f) Lee, H.-M. Chan, D. S.-H.; Yang, F.; Yan, S.-C.; Che, C.-M.; Ma, D.-L.; Leung, C.-H. Chem. Commun. 2010, 4680; (g) Neidle, S. Therapeutic Aspects of Quadruplex Nucleic Acids; Academic Press: San Diego, 2012.

5. Biffi, G.; Tannahill, D.; McCafferty, J.; Balasubramanian, S. Nat. Chem. 2013, 5, $182-186$.

6. (a) Ma, Y. Ou, T.-M.; Tan, J--H. Hou, J-O : Huang, S.-L.; Gu, L--Q : Huang, Z.-S Eur. J. Med. Chem. 2011, 46, 1906; (b) Boddupally, P. V.; Hahn, S.; Beman, C.; De B.; Brooks, T. A.; Gokhale, V.; Hurley, L. H. J. Med. Chem. 2012, 55, 6076.

7. (a) Gunaratnam, M.; Swank, S.; Haider, S. M.; Galesa, K.; Reszka, A. P.; Beltran, M.; Cuenca, F.; Fletcher, J. A.; Neidle, S. J. Med. Chem. 2009, 52, 3774; (b) Bejugam, M.; Sewitz, S.; Shirude, P. S.; Rodriguez, R.; Shahid, R.; Balasubramanian, S. J. Am. Chem. Soc. 2007, 129, 12926.

8. Ohnmacht, S. A.; Micco, M.: Petrucci, V.: Todd, A. K.; Reszka, A. P.; Gunaratnam, M.; Carvalho, M. A.; Zloh, M.; Neidle, S. Bioorg. Med. Chem. Lett. 2012, 22, 5930. 
9. (a) Phan, A. T.; Kuryavyi, V.; Burge, S.; Neidle, S.; Patel, D. J. J. Am. Chem. Soc 2007, 129, 4386; (b) Hsu, S. T.; Varnai, P.; Bugaut, A.; Reszka, A. P.; Neidle, S. Balasubramanian, S. J. Am. Chem. Soc. 2009, 131, 13399; (c) Wei, D.; Parkinson, G. N.; Reszka, A. P.; Neidle, S. Nucleic Acids Res. 2012, 40, 4691; (d) Todd, A. K.; Haider, S. M.; Parkinson, G. N.; Neidle, S. Nucleic Acids Res. 2007, 35, 5799.

10. Yu, H.; Gu, X.; Nakano, S. I.; Miyoshi, D.; Sugimoto, N. J. Am. Chem. Soc. 2012 134,20060

11. Micco, M.; Collie, G. W.; Dale, A. G.; Ohnmacht, S. A.; Pazitna, I.; Gunaratnam, M.; Reszka, A. P.; Neidle, S. J. Med. Chem. 2013, 56, 2959.

12. Dai, J.; Carver, M.; Hurley, L. H.; Yang, D. J. Am. Chem. Soc. 2011, 133, 17673.

13. Lombardo, C. M.; Welsh, S. J.; Strauss, S. J.; Dale, A. G.; Todd, A. K.; Nanjunda, R.; Wilson, W. D.; Neidle, S. Bioorg. Med. Chem. Lett. 2012, 22, 5984.

14. De Armond, R.; Wood, S.; Sun, D.; Hurley, L. H.; Ebbinghaus, S. W. Biochemistry 2005, 44, 16341

15. Moorhouse, A. D.; Santos, A. M.; Gunaratnam, M.; Moore, M.; Neidle, S.; Moses, J. E. J. Am. Chem. Soc. 2006, 128, 15972.

16. Strotman, N. A.; Chobanian, H. R.; Gou, Y.; He, J.; Wilson, J. E. Org. Lett. 2010, 16, 3578.

17. Direct arylation: $3,3^{\prime}-\left(5,5^{\prime}-(1,3-\right.$ phenylene)bis(oxazole-5,2-diyl))bis( $N$-(3-(4methylpiperazine-1-yl)propyl)aniline) $(\mathbf{3}, \mathbf{4})$. An oven dried microwave vial was charged with $\mathrm{Pd}(\mathrm{OAC})_{2}$ (0.1 equiv), $\mathrm{K}_{2} \mathrm{CO}_{3}$ (3 equiv), ligand (2dicyclohexylphosphino-2', $6^{\prime}$-diisopropoxybiphenyl, 0.2 equiv), oxazole precursor (1 equiv) and arylbromide (2.2 equiv). The microwave vial was capped, evacuated and backfilled with argon and then pivalic acid ( 0.4 equiv) and toluene were added. The vial was heated at $110{ }^{\circ} \mathrm{C}$ for $72 \mathrm{~h}$. After cooling to room temperature, the reaction mixture was concentrated and purified using silica gel. ( $\left.400 \mathrm{MHz}, \mathrm{CDCl}_{3}\right) \delta 1.26\left(4 \mathrm{H}, \mathrm{s}, 2 \times \mathrm{CH}_{2}\right), 1.65\left(4 \mathrm{H}, \mathrm{br} \mathrm{s}, 2 \times \mathrm{CH}_{2}\right), 1.85$ $\left(4 \mathrm{H}\right.$, quintet, $\left.J=6.3 \mathrm{~Hz}, 2 \times \mathrm{CH}_{2}\right), 2.31\left(6 \mathrm{H}, \mathrm{s}, 2 \times \mathrm{CH}_{3}\right), 2.51-2.55(12 \mathrm{H}, \mathrm{m}$, $\left.6 \times \mathrm{CH}_{2}\right), 3.30\left(4 \mathrm{H}, \mathrm{t}, J=6.3 \mathrm{~Hz}, 2 \times \mathrm{CH}_{2}\right), 6.72(2 \mathrm{H}, \mathrm{dd}, J=1.6,8.1 \mathrm{~Hz}, 2 \times \mathrm{Ar}-$ $\mathrm{H}), 7.29(2 \mathrm{H}, \mathrm{t}, J=7.8 \mathrm{~Hz}, 2 \times \mathrm{Ar}-\mathrm{H}), 7.35(2 \mathrm{H}, \mathrm{t}, J=1.6 \mathrm{~Hz}, 2 \times \mathrm{Ar}-\mathrm{H}), 7.46(2 \mathrm{H}$, d, $J=7.8 \mathrm{~Hz}, 2 \times \mathrm{Ar}-\mathrm{H}), 7.49-7.53(2 \mathrm{H}, \mathrm{m}, 2 \times \mathrm{Ar}-\mathrm{H}), 7.69(2 \mathrm{H}, \mathrm{dd}, J=1.5$, $7.8 \mathrm{~Hz}, 2 \times \mathrm{Ar}-\mathrm{H}), 8.01\left(1 \mathrm{H}\right.$, br s, Ar-H). ${ }^{13} \mathrm{C}$ NMR $\left(100 \mathrm{MHz}, \mathrm{CDCl}_{3}\right) \delta 162.1$ $(2 \times$ quat $), 150.4(\mathrm{CH}), 149.1(2 \times \mathrm{CH}), 129.7(2 \times \mathrm{CH}), 129.6(2 \times \mathrm{CH}), 129.0$ $(2 \times \mathrm{CH}), 128.1(2 \times \mathrm{CH}), 124.1$ ( $2 \times$ quat $), 124.0$ ( $2 \times$ quat $), 119.7$ ( $2 \times$ quat $)$, $115.3(\mathrm{CH}), 115.2(2 \times \mathrm{CH}), 109.8(2 \times \mathrm{CH}), 57.2\left(2 \times \mathrm{CH}_{2}\right), 55.3\left(4 \times \mathrm{CH}_{2}\right), 53.2$ $\left(4 \times \mathrm{CH}_{2}\right), \quad 46.0\left(2 \times \mathrm{CH}_{2}\right), \quad 43.5\left(2 \times \mathrm{CH}_{2}\right), \quad 25.6\left(2 \times \mathrm{CH}_{3}\right)$. HRMS $\left(\mathrm{ES}^{+}\right)$ calculated for $\mathrm{C}_{40} \mathrm{H}_{50} \mathrm{~N}_{8} \mathrm{O}_{2}[\mathrm{M}+1]^{+} 675.4135$, found 675.4125 .

18. Click reaction: 3,3'-(4,4'-(naphthalene-2,7-diyl)bis(1H-1,2,3-triazole-4,1diyl))bis( $N$-(3-(4-methylpiperazin-1-yl)-propyl) aniline) (1, 2). Dialkyne (1 equiv) was dissolved in the appropriate volume of solvent $\left(\mathrm{H}_{2} \mathrm{O}:{ }^{t} \mathrm{BuOH}\right.$ $1: 1$ ), followed by the addition of required azide ( 3 equiv) and the catalytic mixture of $\mathrm{CuSO}_{4} \times 5 \mathrm{H}_{2} \mathrm{O}$ ( 0.05 equiv), sodium ascorbate ( 0.5 equiv) and bathophenanthroline disulfonic acid disodium salt hydrate (0.1 equiv). The reaction was performed with excess of the required amine ( 6 equiv). The mixture was heated under microwave irradiation for $15 \mathrm{~min}$ at $120^{\circ} \mathrm{C}$. Crude product was obtained following evaporation of solvents and subsequent $\mathrm{C} 18$ reversed phase semi-prep purification. ${ }^{1} \mathbf{H}$ NMR $\left(400 \mathrm{MHz}, \mathrm{CDCl}_{3}\right) \delta 1.81(4 \mathrm{H}$, quintet, $\left.J=6.6 \mathrm{~Hz}, 2 \times \mathrm{CH}_{2}\right), 2.45\left(4 \mathrm{H}, \mathrm{t}, J=6.6 \mathrm{~Hz}, 2 \times \mathrm{CH}_{2}\right), 2.58(6 \mathrm{H}, \mathrm{s}$, $\left.2 \times \mathrm{CH}_{3}\right), 2.67\left(8 \mathrm{H}\right.$, br s, $\left.4 \times \mathrm{CH}_{2}\right), 2.94\left(8 \mathrm{H}\right.$, br s, $\left.4 \times \mathrm{CH}_{2}\right), 4.16(4 \mathrm{H}, \mathrm{t}, J=7.3 \mathrm{~Hz}$, $\left.2 \times \mathrm{CH}_{2}\right), 7.64-7.68(2 \mathrm{H}, \mathrm{m}, 2 \times \mathrm{Ar}-\mathrm{H}), 7.75-7.77(4 \mathrm{H}, \mathrm{m}, 4 \times \mathrm{Ar}-\mathrm{H}), 7.93-8.03$
$(4 \mathrm{H}, \mathrm{m}, 4 \times \mathrm{Ar}-\mathrm{H}), 8.19(2 \mathrm{H}, \mathrm{t}, J=1.8 \mathrm{~Hz}, 2 \times \mathrm{Ar}-\mathrm{H}), 8.46-8.48(4 \mathrm{H}, \mathrm{m}, 4 \times \mathrm{Ar}-$ $\mathrm{H}) .{ }^{13} \mathrm{C}$ NMR $\left(100 \mathrm{MHz}, \mathrm{CDCl}_{3}\right) \delta 148.2(2 \times \mathrm{CH}), 143.2(2 \times \mathrm{CH}), 138.0(2 \times \mathrm{CH})$ 133.6 (quat), 133.3 (quat), $131.0(2 \times \mathrm{CH}), 128.8$ ( $2 \times$ quat), 128.1 ( $2 \times$ quat), $125.0(2 \times \mathrm{CH}), 124.3(2 \times$ quat $), 118.6(2 \times$ quat $), 118.2(2 \times \mathrm{CH}), 118.1$ $(2 \times \mathrm{CH}), 110.7(2 \times \mathrm{CH}), 54.4\left(2 \times \mathrm{CH}_{2}\right), 53.3\left(4 \times \mathrm{CH}_{2}\right), 50.7(4 \times \mathrm{CH} 2), 43.8$ $\left(2 \times \mathrm{CH}_{2}\right), 41.7\left(2 \times \mathrm{CH}_{2}\right), 23.3\left(2 \times \mathrm{CH}_{3}\right)$. HRMS $\left(\mathrm{ES}^{+}\right)$calculated for $\mathrm{C}_{42} \mathrm{H}_{52} \mathrm{~N}_{12}$ $[\mathrm{M}+1]^{+} 725.4516$, found 725.4482 .

19. Sulforhodamine B assay (SRB). Cells were counted and diluted to the required concentration in $20 \mathrm{~mL}$ medium. For cell lines MCF7, A549, RCC4 and 786-0, 1000-4000 cells with $160 \mu \mathrm{L}$ media (WI38: 6000/well) were seeded into each well of a 96 well plate (Nunc, Denmark). After incubation for $24 \mathrm{~h}$, the compound to be tested was dissolved in $40 \mu \mathrm{L}$ of medium and was added in a range of concentrations, and the cells incubated for $96 \mathrm{~h}$. The medium was then removed and the cells fixed by incubation with TCA (10\%, Sigma-Aldrich, UK) for $30 \mathrm{~min}$ at $4{ }^{\circ} \mathrm{C}$. After removal of the TCA, the cells were washed with deionised water five times and dried at $60^{\circ} \mathrm{C}$ for $1 \mathrm{~h}$. The cells were then incubated with sulforhodamine B $(80 \mu \mathrm{L}, 0.4 \%$ in $1 \%$ acetic acid, Acros Organics, UK) for $15 \mathrm{~min}$ at rt. The SRB was removed, the wells washed with $1 \%$ acetic acid $(200 \mu \mathrm{L})$, and dried at $60^{\circ} \mathrm{C}$ for $1 \mathrm{~h}$. Tris-base $(100 \mu \mathrm{L}, 10 \mathrm{mM}$, Acros Organics, UK) solution was added to each well, and the plates were gently shaken for $5 \mathrm{~min}$. The absorbance at $540 \mathrm{~nm}$ was measured with a plate reader (Spectrostar Omega, BMG Labtech, Germany). The data were normalized to the value of 100 for the control experiment (untreated cells), and the $\mathrm{IC}_{50}$ values were obtained by interpolation from a plot with Origin (Version 7.0, OriginLab Corp.), as the concentration leading to an absorbance intensity of $50 \%$.

20. FRET DNA melting assays on compounds 1-8 were performed as previously described (Guyen, B. Schultes, C. M. Hazel, P. Mann, J. Neidle, S. Org. Biomol. Chem. 2004, 2, 981) using a fluorescence resonance energy transfer (FRET) assay modified as a high-throughput screen in a 96-well format. The labelled oligonucleotides had attached the donor fluorophore FAM: 6carboxyfluorescein and the acceptor fluorophore TAMRA: 6carboxytetramethyl-rhodamine. The FRET probe sequences were diluted from stock to the correct concentration $(400 \mathrm{nM})$ in a $60 \mathrm{mM}$ potassium cacodylate buffer ( $\mathrm{pH} 7.4$ ) and then annealed by heating to $95^{\circ} \mathrm{C}$ for $10 \mathrm{~min}$, followed by cooling to room temperature in the heating block (3-3.5 h). The compounds were stored as a $1 \mathrm{mM}$ stock solution in 10\% DMSO/90\% $1 \mathrm{mmol}$ $\mathrm{HCl}$; final solutions (at $2 \times$ concentration) were prepared using $60 \mathrm{mM}$ potassium cacodylate buffer ( $\mathrm{pH} 7.4$ ). Relevant controls using BRACO-19 (in addition to blank runs) were also performed to check for quality of DNA samples (e.g., F21T). 96-Well plates (MJ Research, Waltham, MA) were prepared by aliquoting $50 \mu \mathrm{L}$ of the annealed DNA into each well, followed by $50 \mu \mathrm{L}$ of the compound solutions. Measurements were made on a DNA Engine Opticon (MJ Research) with excitation at 450-495 nm and detection at $515-545 \mathrm{~nm}$. Fluorescence readings were taken at intervals of $0.5^{\circ} \mathrm{C}$ in the range $30-100^{\circ} \mathrm{C}$, with a constant temperature being maintained for $30 \mathrm{~s}$ prior to each reading to ensure a stable value. Final analysis of the data was carried out using a script written in the program Origin 7.0 (OriginLab Corp., Northampton, MA). The advanced curve-fitting function in Origin 7.0 was used for calculation of $\Delta T_{\mathrm{m}}$ values. Esds in $\Delta T_{\mathrm{m}}$ are $\pm 0.1^{\circ} \mathrm{C}$.

21. Parkinson, G. N.; Lee, M. P. H.; Neidle, S. Nature 2002, 417, 876. 